\title{
Transformation in a Nutritionally Deficient Mutant of Candida pseudotropicalis
}

\author{
By B. L. FRYE, J. H. LANCASTER AND H. W. LARSH \\ Department of Botany and Microbiology, The University of Oklahoma, \\ Norman, Oklahoma, 73069, U.S.A.
}

(Received 27 February 1973; revised 4 April 1973)

\begin{abstract}
SUMMARY
Data from two experiments indicated that transformation occurred in Candida pseudotropicalis in the conversion of lactose-negative to lactose-positive cells. When the DNA from prototrophic cells was mixed in media with auxotrophic cells approximately $0.1 \%$ of the recipient cells were transformed to prototrophs.

Transformation activity of the donor DNA was found to diminish with heat, DNase or 2-deoxyglucose. The frequencies of transformation obtained in this study compare with those observed in other fungi and some bacteria.
\end{abstract}

\section{INTRODUCTION}

Successful transformation experiments have been reported in a number of bacteria. The following genera have been included in these reports: Hemophilus, Pneumococcus, Neisseria, Streptococcus, Bacillus, Staphylococcus, Rhizobium, Escherichia, Shigella and in Salmonella (Braun, 1965). Transformation studies have also been conducted with fungi. Oppenoorth (1960) reported transformation of Saccharomyces chevalieri. The DNA from the donor conferred the ability to ferment certain sugars on a deficient yeast. Shamoian, Canzanelli \& Melrose (196I) reported the transformation of Neurospora crassa, and Shockley \& Tatum (I962) believed their results provided suggestive but not convincing evidence of transformation in nutritionally deficient mutants of $N$. crassa. A Candida albicans transformant produced by nucleoproteins from Mycobacterium tuberculosis was obtained by Kwapinski (1968) and the transformant differed biochemically and serologically from the parental strain. Transformation of Aspergillus niger was reported by Mishra \& Sen (1969) and Sen, Nandi \& Mishra (1969) while interspecific transformation between Alloymces arbusculus and A. macrogynus was reported by Turian \& Ojha, 1969).

\section{METHODS}

Organism. Candida pseudotropicalis was obtained from the American Type Culture Collection as ATCC 9767 .

Isolation of mutants. Auxotrophic mutants were obtained by exposure to u.v. irradiation for $20 \mathrm{~min}$ at a distance of $15 \mathrm{~cm}$ from a germicidal lamp source (General Electric G 45I I, $4 \mathrm{~W}$ ). The mercury light source produces strong radiation at $243.7 \mathrm{~nm}$ and was calibrated after use and found to provide $6 \cdot 78 \times 10^{14}$ photons $/ \mathrm{s} / \mathrm{cm}^{2}$ at the distance used $\left(5 \cdot 307 \times 10^{3} \mathrm{ergs} /\right.$ $\mathrm{s} / \mathrm{cm}^{2}$ ). This value was obtained from the photolysis of uranyl oxalate using a relationship established between the amount of light absorbed and the amount of chemical action produced by Leighton \& Forbes (1930). Irradiated cultures were placed in the dark overnight 
Table r. Control experiments in the transformation of Candida pseudotropicalis

Components were added to basic glucose minimal culture media and incubated at $35^{\circ} \mathrm{C}$ for $24 \mathrm{~h}$. Samples were then plated on minimal agar as described in methods.

No. of colonies appearing

\section{Components}

IO $0^{5}$ Recipient cells

$50 \mu \mathrm{g} / \mathrm{ml}$ DNA

Heat-treated DNA and $10^{5}$ recipient cells

$\mathrm{IO}^{2}$ donor cells

Media not inoculated

DNase-treated DNA and $10^{5}$ recipient cells

Auxotrophic DNA and $10^{5}$ recipient cells on chemically defined agar

and then allowed to grow in the laboratory for 3 days at $27^{\circ} \mathrm{C}$. Colonies, obtained by subculturing, were tested for their ability to ferment a number of carbohydrates. One mutant, unable to ferment lactose, was selected and used in both experiments.

Isolation of deoxyribonucleic acid. Forty-eight-hour-old cultures were harvested by centrifugation and washed twice with a solution containing $0 . \mathrm{I}$ M-ethylenediaminetetraacetate and $0.15 \mathrm{M}-\mathrm{NaCl}$. The pellet was placed in $\mathrm{I} \mathrm{M}$-sorbitol and $20 \%(\mathrm{v} / \mathrm{v})$ glycerol, and this suspension was poured into a cold high-pressure cylinder of a Sorvall ribi cell fractionator, model RF-I, with the fill and ribi valves removed. The frozen mixture was placed in the fractionator and forced through a high-pressure line $2 \mathrm{~cm}$ long having an internal diameter of $0.95 \mathrm{~mm}$ with a pressure of $20000 \mathrm{lb} / \mathrm{in}^{2}$. The procedure of Marmau (I96I) was used for the isolation of DNA from the viscous, lysed suspension. The solution was dialysed overnight at $4{ }^{\circ} \mathrm{C}$ against 1000 volume saline-citrate, reprecipitated in ethyl alcohol and stored at $5{ }^{\circ} \mathrm{C}$. DNA was determined by the colorimetric diphenylamine method using a sperm DNA preparation as the standard. The mol. wt of the preparation varied from 2 million to 20 million with an average size of 10 million as determined in a sucrose gradient using a $0.05 \mathrm{ml}$ sample of DNA centrifuged at $64000 \mathrm{rev} . / \mathrm{min}$ for $\mathrm{I} \mathrm{h}$. The gradient was then examined in an u.v. analyser (Isco Model UA-2 u.v. liquid flow analyser) and the position of the DNA sample in the gradient recorded. The mol. wt was determined from tables containing known values.

Protocol of transformation experiment. Recipient cultures, unable to ferment lactose, were grown to the logarithmic phase in basic glucose minimal medium on a rotary shaker at $35^{\circ} \mathrm{C}$. This medium comprised (per litre): $\mathrm{NH}_{4} \mathrm{Cl}, 2.5 \mathrm{~g} ; \mathrm{KH}_{2} \mathrm{PO}_{4}, 7 \cdot 0 \mathrm{~g} ; \mathrm{NaHPO}_{4}, 7 \cdot 2 \mathrm{~g}$; $\mathrm{MgSO}_{4} .7 \mathrm{H}_{2} \mathrm{O}, 0.2 \mathrm{~g}$; NaCl, O.I g; glucose, $3.0 \mathrm{~g}$; thiamin hydrochloride, I50 $\mu \mathrm{g}$; biotin, I $50 \mu \mathrm{g}$; nicotinic acid, I $50 \mu \mathrm{g}$; calcium pantothenate, I50 $\mu \mathrm{g}$. One $\mathrm{ml}$ portions of the suspension were transferred to $100 \mathrm{ml}$ of culture media plus wild-type DNA suspended in I $\mathrm{ml}$ of saline-citrate and incubated for $24 \mathrm{~h}$ on a low-speed rotary shaker at $35^{\circ} \mathrm{C}$. The DNA concentration in the culture medium was varied from 25 to $100 \mu \mathrm{g} / \mathrm{ml}$. The exposure to DNA was terminated by the addition of $100 \mu \mathrm{g}$ of crystalline pancreatic deoxyribonuclease prepared in $0.03 \mathrm{M}-\mathrm{MgSO}_{4}$ at the end of the $24 \mathrm{~h}$ period. The organisms were centrifuged, washed twice, and then suspended in $0.9 \% \mathrm{NaCl}$, and $10^{5}$ were spread on minimal agar containing per litre the same composition as the basic glucose minimal medium but with lactose substituted for glucose and $13.5 \mathrm{~g}$ agar added. The ingredients were autoclaved for 15 min at $12 \mathrm{I}{ }^{\circ} \mathrm{C}$ (except lactose) which was sterilized by filtration through a Selas filter and added separately to the liquid agar. The plates were incubated at $27{ }^{\circ} \mathrm{C}$ for 4 to 5 days. 
Table 2. Number of transformants related to DNA concentration and growth medium

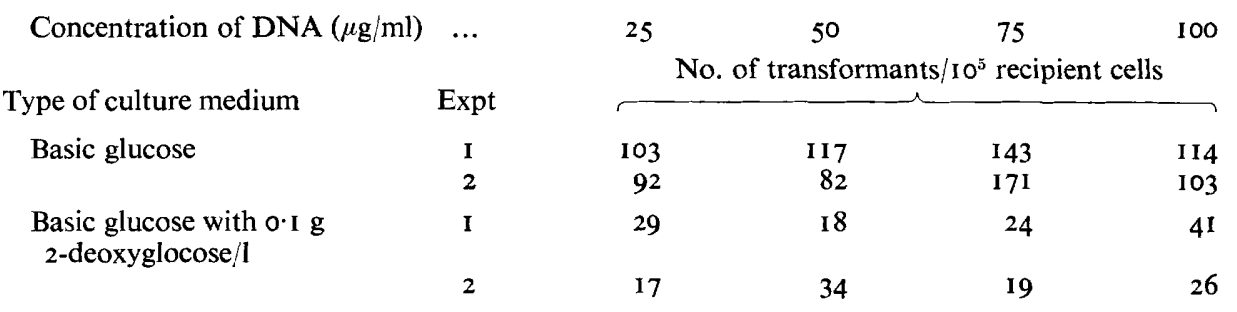

Colonies were randomly selected from each plate and individually transferred to another plate of minimal agar, incubated at $25^{\circ} \mathrm{C}$ for 5 days, and then transferred to $10 \mathrm{ml}$ phenol red lactose broth (Difco). All samples tested were capable of fermenting lactose. Two consecutive experiments were conducted with similar results.

Control procedures. The results of control experiments are shown in Table I. One $\mathrm{ml}$ solution containing $50 \mu \mathrm{g}$ donor DNA was heated in a water bath to $100{ }^{\circ} \mathrm{C}$ for $10 \mathrm{~min}$. The tube was removed from the water bath and placed in an ice chest for rapid cooling. The DNA solution was added to recipient cells in basic glucose minimal medium and incubated as above. Donor cells were plated to determine the period of incubation necessary for the appearance of wild-type colony formation, and auxotrophic DNA was incubated with recipient cultures. Other controls included a $50 \mu \mathrm{g}$ preparation of DNA incubated with I00 $\mu \mathrm{g}$ of $\mathrm{Mg}$-activated DNase solution at $37^{\circ} \mathrm{C}$ for $30 \mathrm{~min}$ which was then added to recipient cells. Samples of DNA without recipient cells and recipient cells without DNA, incubated as the DNA-treated cells, were also spread on minimal agar. The sterility of the media used was determined by incubating plates that were not inoculated. The usual precautions of sterility for solutions and equipment were observed throughout the experiment.

\section{RESULTS AND DISCUSSION}

Effect of heat on transformation. Transformation activity was found to diminish with heat (Tables I, 2), although the average number of transformants was higher than for recipient cultures plated alone. The colonies appearing from recipient cultures without DNA treatment and from recipient cells treated with auxotrophic DNA are most likely due to spontaneous back mutation. The average frequency of transformation obtained at all concentrations of DNA with basic glucose minimal medium is $0.12 \%$. When this value is corrected by subtracting the percentage obtained with untreated recipient cultures, the transformation frequency is $0.119 \%$.

Effect of 2-deoxyglucose on transformation. In two experiments (Table 2) the presence of 2-deoxyglucose (Schwarz \& Mann) reduced the number of transformants. Johnson (I968) and Svoboda, Farkas \& Bauer (1969) reported the inhibition of cell-wall synthesis with this chemical. There is evidence that the ability to absorb DNA is correlated with the chemical composition of the cell surface and the entire apparatus for uptake may reside in the recipient cell. DNA may exist for a period of time between the wall and the plasma membrane of the cell. Numerous studies have implicated the cell wall with the absorption of DNA in bacteria (see Hayes, 1970). Candida pseudotropicalis, growing in 2-deoxyglucose, was examined for evidence of reduced cell-wall components. When viewed under 1000 magnification, the cells appeared thinner when compared to cells from basic glucose medium using Webb's cell-wall stain. 
Effect of DNase on transformation. When DNA was incubated with DNase prior to adding recipient cultures in basic glucose medium, the transforming activity was greatly reduced (Table I).

No effect of supernatant fluid on transformation frequency could be demonstrated.

This investigation was supported in part by a Science Faculty Fellowship from the National Science Foundation, Washington, D.C. 20500.

\section{REFERENCES}

Braun, W. (1965). Bacterial Genetics, pp. 239-264. Philadelphia \& London: W. B. Saunders Company. HAYES, W. (1970). The Genetics of Bacteria and their Viruses; chapter 20: Transformation. New York: John Wiley \& Sons.

JoHNSON, B. F. (1968). Lysis of yeast cell walls induced by 2-deoxyglucose at their sites of glucan synthesis. Journal of Bacteriology 95, $1169-1172$.

KWAPINSKI, J. B. (1968). A Candida transformant produced by mycobacterial nucleic acids. Antonie van Leuwenhoek 34, 57-65.

LeIGHTON, P. A. \& Forbes, G. S. (1930). Precision actinometry with uranyl oxalate. Journal of the American Chemical Society 52, 3139-3152.

MARMUR, J. (1961). A procedure for the isolation of deoxyribonucleic acid from micro-organisms. Journal of Molecular Biology 3, 208-218.

Mishra, A. K. \& SEN, K. (I969). Transformation of a biochemically deficient mutant of Asperigillus niger. Current Science 38, 395-396.

OPPENOORTH, W. F. F. (1960). Modification of the hereditary character of yeast by ingestion of cell-free extracts. Antonie van Leuwenhoek 26, I29-168.

SEN, K., NANDI, P. \& Mishra, A. K. (1969). Transformation of nutritionally deficient mutants of Asperigillus niger. Journal of General Microbiology 55, 195-200.

Shamoian, C. A., Canzanelli, A. \& Melrose, J. (I96I). Back-mutation of a Neurospora crassa mutant by a nucleic acid complex from the wild strain. Biochimica et biophysica acta 47, 208-211.

ShockLEY, T. E. \& TATUM, E. L.(1962). A search for genetic transformation in Neurospora crassa. Biochimica et biophysica acta 6r, 567-572.

Svoboda, A., Farkas, V. \& BaUer, S. (1969). Response of yeast protoplasts to 2-deoxyglucose. Antonie van Leuwenhoek 35, BII.

TuRIAN, G. \& OJHA, M. N. (1969). Indications of an interspecific transformation in Allomyces. Experientia $25,79-8 \mathrm{I}$. 